\title{
MITES (ARACHNIDA: ACARI) ON COFFEE PLANTS IN FOREST FRAGMENT AND CONVENTIONAL PLANTATION IN MONTE ALEGRE DO SUL, STATE OF SÃO PAULO, BRAZIL
}

\author{
Jeferson Luiz de Carvalho Mineiro*, Mário Eidi Sato, \\ Luiz Henrique Chorfi Berton \& Adalton Raga
}

Instituto Biológico, Centro Avançado de Pesquisa em Proteção de Plantas e Saúde Animal, Laboratório de Entomologia Econômica. Alameda dos Vidoeiros, $n^{\circ}$ 1097. CEP 13101-680. Gramado, Campinas, São Paulo, Brasil. *E-mail: jefmin@hotmail.com

\section{RESUMO}

\section{ÁCAROS (ARACHNIDA: ACARI) DE PLANTAS DE CAFÉ EM FRAGMENTOS} DE FLORESTA E PLANTAÇÃO CONVENCIONAL EM MONTE ALEGRE DO SUL, ESTADO DE SÃO PAULO, BRASIL

Alguns poucos trabalhos foram desenvolvidos no Brasil sobre ácaros em cafeeiros e em fragmentos florestais adjacentes. Contudo, não há nenhuma informação sobre ácaros associados a cafezais no interior de fragmentos florestais. Portanto, neste estudo, objetivou-se conhecer a acarofauna em cafeeiros no interior de fragmentos florestais. O estudo foi conduzido em duas áreas no município de Monte Alegre do Sul. Em uma das áreas, o cafeeiro foi cultivado de maneira convencional e em outra as plantas, sem qualquer trato cultural, encontravam-se no interior de remanescente de floresta estacional semidecidual. Um total de 549 ácaros foi encontrado, no período estudado, sendo 284 em plantas de cafeeiro no interior dos fragmentos florestais e 265 em cafeeiros cultivados. Ao todo, foram encontradas 25 espécies, em 16 famílias, distribuídas em quatro ordens. A riqueza de espécies de ácaros, observada nos dois ambientes, foi semelhante: 17 e 15, respectivamente. Foi constatado um claro contraste entre a estrutura da acarofauna no interior do fragmento florestal e na do cultivo convencional, com alta abundância de ácaros fitófagos [Brevipalpus spp., Oligonychus yothersi (McGregor)] na produção convencional e alto número de predadores [Iphiseiodes matatlanticae Mineiro, Castro \& Moraes and Amblyseius herbicolus (Chant)] no interior do fragmento. $O$ índice de similaridade de Sørensen entre os dois ambientes foi de 0,25.

PALAVRAS-CHAVE: Coffea arabica, estrutura da comunidade acarina, Phytoseiidae, Iphiseiodes matatlanticae, Oligonychus yothersi. 


\section{ABSTRACT}

Despite the importance of the mites in coffee and the increased relevance of agroforest systems, there is practically no information on the acarofauna associated with coffee plants in forest environments in Brazil. Therefore, the objective of this study was to evaluate the mites on coffee plants in a forest fragment and compare it to that of a coffee conventional plantation. The study was conducted in two areas with coffee plants in the municipality of Monte Alegre do Sul, in the State of São Paulo, Brazil. In the first area, the coffee plants without management were in a fragment of a semi-deciduous seasonal forest and, in the second area, the coffee plants were in a conventional plantation. A total of 549 mites were collected in this period: 284 on coffee plants within the forest fragment and 265 on a conventional coffee plantation. The collected mites were classified in 25 species, 16 families and four orders. The mite species richnesses of both environments were similar to each other, with 17 and 15 species, respectively. Clear contrasts between the coffee mite community of the forest fragment and of the coffee plantation, with higher abundance of phytophagous mites [e.g. Brevipalpus spp., Oligonychus yothersi (McGregor)] in the conventional production area and higher number of predaceous mites [e.g. Iphiseiodes matatlanticae Mineiro, Castro \& Moraes and Amblyseius herbicolus (Chant)] on coffee plants within the forest fragment. The Sørensen similarity index estimated for the mite species of these two environments was of 0.25 .

KEYWORDS: Coffea arabica, Acari community structure, Phytoseiidae, Iphiseiodes matatlanticae, Oligonychus yothersi.

The study of the insects and mites living in the natural vegetation may provide fundamental knowledge for applied biological control of agricultural pests, which can be originated from natural habitats where they rarely reach high population levels. The knowledge of the host plants and the system in which they are inserted are also of fundamental importance for the environmental restructuration, in order to make it more favorable to the establishment of natural enemies (Gerson et al., 2003; HoY, 2011).
A few studies have been conducted in Brazil on mites in coffee plantations and the influence of adjacent forest fragments on the mite community (SILVA et al., 2010); however, there is no information in the literature on mites associated with coffee plants cultivated within forest fragments.

The study was carried out aiming at evaluating the acarofauna on coffee plants cultivated in a forest fragment and to compare it to that of a coffee conventional plantation in the State of São Paulo (Atlantic Forest biome). The study was conducted in the municipality of 
Monte Alegre do Sul, State of São Paulo, in the Serra da Mantiqueira (Mantiqueira Mountains), within the Atlantic Forest biome.

The acarofauna was evaluated in two different areas and the distance between them (forest fragment and conventional coffee plantation) was approximately 3

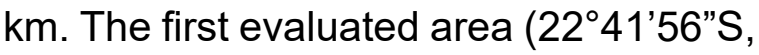
$46^{\circ} 40^{\prime} 02$ "W, $750 \mathrm{~m}$ ) was in a forest fragment in the experimental field of Polo APTA Leste Paulista (Research Institute of the Government of the State of São Paulo). In this area, the coffee plants ( $2.2 \mathrm{~m}$ tall) were established in the middle of native forest plants. The distance between coffee plants was of 5 to $10 \mathrm{~m}$, with at least one or two forest plants in the space separating the coffee plants. The second evaluated area (22 $41^{\circ}$ '59"S, $46^{\circ} 39^{\prime} 28^{\prime \prime} \mathrm{W}, 755 \mathrm{~m}$ ), with approximately $1,000 \mathrm{~m}^{2}$, was a conventional coffee plantation, located at São José farm. The coffee plants were of approximately 30 years old and $2 \mathrm{~m}$ tall. Plants were spaced $3.0 \mathrm{~m}$ within the row and $3.0 \mathrm{~m}$ between rows. This coffee area was bordered laterally by a Semi-deciduous Seasonal Forest remnant.

The samples were taken from coffee plants within conventional cultivation area and in the forest fragment. Twelve leaves per plant from 10 plants of Coffea arabica L. were collected monthly from each evaluated area. In the case of the coffee conventional area, the samples were taken from the plants located in the inner part of the cultivated area, distant at least $30 \mathrm{~m}$ from the forest fragment.

The leaves were collected from the middle portion of the coffee branches ( $4^{\text {th }}$ or $5^{\text {th }}$ leaf pair). The samplings were conducted from October 2007 to October 2008. The leaves were brought into the laboratory and immersed for 5 minutes in a solution of water and detergent ( 0.5 $\%)$. The solution was agitated to dislodge the mites from the leaf samples. After removing the leaves, the content of the solution was passed through a sieve with a wire mesh opening of $0.038 \mathrm{~mm}$. The mites retained on the screen were kept in alcohol $70 \%$.

All collected mites from coffee plants were mounted on microscope slides in Hoyer's medium. "Voucher species" were deposited in the Reference Mite Collection "Geraldo Calcagnolo", kept in the Laboratory of Acarology, of Instituto Biológico, in Campinas, State of São Paulo (ICMBio authorization 35919-1).

The PAST program (HAMMER et al., 2017) was used to calculate species richness, abundance and diversity index (Shannon) for the mites of coffee plants of both cultivation systems. Sørensen's index was used to measure the similarity of mite species between the two evaluated areas (forest fragment and coffee conventional cultivation area) (MAgurRan, 1988). Relative abundance (WHITTAKER, 1965) was used for the comparison of the mite species between the two environments. 
A total of 549 mites were collected from coffee trees in the interior of the forest fragment and in the conventional cultivation system in Monte Alegre do Sul. These mites were distributed in 25 species, 15 families and four orders (Table 1). For several specimens collected on coffee plants within the forest fragment, it was not possible to identify the species due the lack of available taxonomic keys for specific identification.

The richness of mite species observed in both environments was similar, with 17 and 15 species, on coffee plans in forest and in conventional plantation, respectively (Table 1 ). The diversity index was very close in both environments and there was no significant difference between them ( $t=0.6539, p=0.5134)$. For both environments, only three species accounted for at least $85 \%$ of the total number of mites found on the coffee plants. The dominant species were different for each evaluated environment.

Differences in mite community structure were detected between the two environments, considering the coffee plants inside the forest fragment and those of the conventional cultivation area (Figure 1). The Sørensen similarity index estimated for these environments was of 0.25 . Predatory mites were approximately ten times more abundant in the forest than in the conventional coffee plantation; however, the number of phytophagous mites was much higher in the conventional plantation, with a proportion 13 times higher than that observed for the coffee plants in the forest fragment (Figure 1).

In order to observe the contrasts in the species dominance for both environments, the mite species were classified in descending order of relative abundance (Figures 2A, 2B). In both sites, a few mite species were dominant and most species were of rare occurrence.

The phytophagous mites represented approximately $71 \%$ of the total of mites collected in the conventional coffee (Figure 2B). Brevipalpus mites were dominant ( $40 \%$ of the mites) in the conventional coffee plantation, but within the forest fragment, this species represented only $5 \%$ of the mites (Figures 2A, 2B). All the Brevipalpus mites collected from the coffee plants were of the group Brevipalpus phoenicis (Geijskes) sensu lato (BEARD et al., 2015), including specimens of Brevipalpus papayensis Baker and/or Brevipalpus yothersi Baker (MineIRo, SATO, 2017). Oligonychus yothersi (McGregor) represented approximately $30 \%$ of the mites in conventional coffee; however, it was not found inside the forest fragment (Table 1, Figure 2B).

In the case of predaceous mites, they represented $76 \%$ of the mites in the coffee plants within the forest fragment (Table 1, Figure 2A). Iphiseiodes matatlanticae Mineiro, Castro \& Moraes and Amblyseius herbicolus (Chant) (Acari: Phytoseiidae) were the dominant species on coffee plants in the forest fragment, representing together approximately $75 \%$ the mites; 
however, in the conventional coffee plantation, these two species accounted for only $3 \%$ of the mites (Table 1 , Figures 2A, 2B). Euseius alatus De Leon (Acari: Phytoseiidae), was found only in the conventional coffee area, with a similar abundance $(\sim 3 \%)$ as $A$. herbicolus. These predaceous mites represented together $83 \%$ of the phytoseiid mites in this coffee area.

In the present study, clear differences were observed between the mite communities on coffee plants in a forest fragment and in a conventional plantation, with higher abundance of phytophagous mites in the conventional production area and higher number of predatory mites on coffee plants inside the forest. The diversity of the coffee mites within the forest fragment probably resembles that of the plants of their surroundings (CASTRO, MORAES, 2010; DeMITE et al., 2013) and is probably associated with the heterogeneity of habitats inside the forest fragment, with greater diversity of plants and wide variety of niches.

The richness of mite species observed on coffee trees in the forest fragment (17) was similar or slightly lower than that (23) reported by TEODORO et al. (2009) for coffee plants in agroforestry system in Ecuador. According to these authors, species richness of coffee mites was negatively affected by management intensification, with higher number of mite species in less-disturbed and abandoned agroforests compared with simple- shade agroforests, in the dry season (TEODORO et al., 2009).

It was observed a clear contrast between the most abundant species on coffee plants of both coffee production systems, with high proportion of phytoseiid mites (I. matatlaticae, $A$. herbicolus) in the forest fragment, and high proportion of phytophagous mites (Brevipalpus spp., O. yothersi) in the conventional coffee area. Several factors like the presence of a single crop (coffee) that provides extensive supplies for the phytophagous mites and limits the reservoir of the natural enemies (GERSON et al., 2003; HoY, 2011), elimination of competitors by the use of pesticides (REIS, ZACARIAS, 2007), and the influence of agrochemicals, may have contributed to the increase in abundance of pest mites in the conventional coffee area.

A relatively high abundance of $O$. yothersi in coffee plantation, as observed in the present study, was also reported by OchOA et al. (1991) in Costa Rica, where this species is considered a pest of economic importance. Although relatively abundant in the conventional coffee area, $O$. yothersi was not found on coffee plants within the forest fragment. This fact may be associated with presence of phytoseiid mites like I. matatlanticae and $A$. herbicolus, which may play an important role in the biological control of $O$. yothersi in the forest fragment. In this aspect, $A$. herbiculus was considered an important natural enemy of Oligonychus ilicis (McGregor) in coffee 
plants in agroforestry system in Ecuador (TEODORO et al., 2009).

Other possible factors which may be associated with the absence of $O$. yothersi on the coffee plants in the forest fragment are the higher humidity and more shaded characteristics of this environment, in comparison with those of the conventional coffee area. A negative influence of the high humidity on Oligonychus mites was also mentioned by PALLINI FILHO et al. (1992), FRANCO et al. (2008) and PEDRO NETO et al. (2010). These authors reported that the lowest incidence of $\mathrm{O}$. ilicis on coffee coincided with the rainy season in the State of Minas Gerais, Brazil.

Brevipalpus mites were also in much lower proportion on coffee trees in forest fragment than in coffee plantation in Monte Alegre do Sul. The low incidence of Brevipalpus sp. in the forest fragment is probably related to the negative effect of the phytoseiid mites, abundant in this environment. In the case of $A$. herbicolus, REIS et al. (2007) reported that each female of this predaceous mite was able to kill up to 127 Brevipalpus mites per day, on coffee leaves, under laboratory conditions. In Ecuador, mites of the genus Brevipalpus were also found in reduced number in agroforestry coffee trees (TEODORO et al., 2009).

Although the coffee plantation area in Monte Alegre do Sul was bordered by a forest fragment, it was observed a high proportion of pest mites on coffee trees of this cultivation area. This result indicates that the possible migration of predaceous mites (TIXIER et al., 2000; JUNG, CROFT, 2001) from the forest fragment was not sufficient to prevent the increase of the phytophagous mite abundance in the conventional coffee area. In this aspect, it should be considered that the evaluated coffee plants were at least $30 \mathrm{~m}$ distant from the adjacent forest fragment, reducing the interaction possibilities among the mites from these different environments.

The influence of the acarofauna from adjacent forest fragment on the diversity and abundance of mites in coffee plantation was also reported by SILVA et al. (2010). In the present study, one of the possible influence of the adjacent forest fragment on the mite community of the conventional coffee cultivation was the occurrence of $A$. herbicolus in the coffee plantation. SILVA et al. (2010) also reported that $A$. herbicolus was abundant in coffee plantations located near forest fragments in the southern part of the State of Minas Gerais.

The relative high abundance of $A$. herbicolus on coffee plants in the evaluated forest fragment is probably associated with the climate characteristics of that area. Some studies indicated higher incidence of this species in regions with dry and cold winter conditions (SPONGOSKI et al., 2005) as observed in Monte Alegre do Sul. Amblyseius herbicolus was also found on coffee plants in other regions, with different climate conditions, in the State of São Paulo, but the abundance 
of this phytoseiid mite was low (MINEIRO et al., 2006a, 2006b, 2008a, 2009). SPONGOSKI et al. (2005) also reported that $A$. herbicolus was an abundant predaceous mites in a coffee plantation, in the Brazilian cerrado (savanna) biome in the municipality of Patrocínio, State of Minas Gerais, which is characterized by a dry and cold winter. In Ecuador, TEODORO et al. (2009) also verified that, among the phytoseiid species, A. herbicolus was the most abundant, mainly in the driest period of the year on coffee plants in agroforestry system.

Iphiseiodes matatlanticae was the most abundant species on coffee plants in the forest fragment; however, it was found in a very low proportion ( $0.4 \%$ ) in the coffee conventional plantation. A possible explanation for this fact is the higher susceptibility of this predaceous mite to the pesticides used by the coffee growers, in Monte Alegre do Sul.

Euseius citrifolius Denmark \& Muma was another phytoseiid mite found on coffee trees within the forest fragment, but in a very small number in this environment. E. citrifolius is a common predator in some coffee producing regions in the State of São Paulo (MıNEIRo et al. 2006a,
$2006 \mathrm{~b})$ and is considered an important natural enemy of phytophagous mites like Brevipalpus spp. (MINEIRO et al., 2008b) and O. ilicis (FRANCo et al., 2007). The low incidence of this species in the forest fragment, in Monte Alegre do Sul, may be associated with the unfavorable environmental conditions (PEDRO NETO et al., 2010) and the competition with other predaceous mites (MINEIRO et al., 2008b; SILVA et al., 2015).

The great abundance of phytoseiids I. matatlanticae and $A$. herbicolus suggest the importance of these species as natural enemies of phytophagous mites on coffee; however, in the case of $I$. matatlanticae, there is almost no information on the predation capacity or its potential use in the biological control of pest mites on coffee or other crops.

Further studies are still necessary to understand the possible interactions among the different mite species (especially phytoseiid and pest mites) and the favorable environmental conditions for the predaceous mites on coffee plants, for the improvement of the integrated pest management programs on coffee in Brazil. 


\section{ACKNOWLEDGEMENT}

TheauthorsarethankfultotheFAPESP Technological Development) for the (São Paulo Research Foundation) for research fellowship provided to the third funding this research (Processes \# and fourth authors. We are also grateful 2007/08612-4 and 2016/06919-4) and to Mr. Valdir Rossi, who kindly gave us to Embrapa-Café (Consórcio Pesquisa his permission to carry out the study on Café) for the scholarship to the first author; also, thanks go to CNPq-Brazil the coffee plantation (São José farm) in Monte Alegre do Sul.

(The National Council for Scientific and

\section{REFERENCES}

BEARD, J.J.; OCHOA, R.; BRASWELL, W.E.; BAUCHAN, G. Brevipalpus phoenicis (Geijskes) species complex (Acari: Tenuipalpidae), a closer look. Zootaxa, v.3944, n.1, p.1-67, 2015.

CASTRO, T.M.M.G.; MORAES G.J. DE. Diversity of phytoseiid mites (Acari: Mesostigmata: Phytoseiidae) in the Atlantic Forest of São Paulo. Systematics and Biodiversity, v.8, p.301-307, 2010.

DEMITE, P.R.; LOFEGO, A.C.; FERES, R.J.F. Mite (Acari; Arachnida) diversity of two native plants in fragments of a semideciduous seasonal forest in Brazil. Systematics and Biodiversity, v.11, p.141-148, 2013.

FRANCO, R.A.; REIS, P.R.; ZACARIAS M.S.; ALTOÉ B.F. Potencial de predação de três espécies de fitoseídeos sobre Oligonychus ilicis (McGregor, 1917) (Acari: Tetranychidae). Coffee Science, v.2, p.175-182, 2007.

FRANCO, R.A.; REIS, P.R.; ZACARIAS, M.S.; ALTOÉ, B.F.; PEDRO NETO, M. Dinâmica populacional de Oligonychus ilicis (McGregor, 1917) (Acari: Tetranychidae) em cafeeiro e de fitoseídeos associados a ele. Coffee Science, v.3, p.38-46, 2008.

GERSON, U.; SMILEY, R.L.; OCHOA, R. Mites for pest control. Oxford: Blackwell Science, 539pp. 2003.

HAMMER, Ø.; HARPER, D.A.T.; RYAN, P.D. PAST - Palaentological Statistics, version 3.17. [Internet] - [Nov 2017]. Oslo: UiO/Natural History Museum; [20 Nov 2017]. Available from: http://folk.uio.no/ohammer/past.

HOY, M.A. Agricultural Acarology: Introduction to integrated mite management. Boca Raton: CRC Press, 410pp., 2011.

JUNG, C.; CROFT, B.A. Aerial dispersal of phytoseiid mites (Acari: Phytoseiidae): Estimating falling speed and dispersal distance of adult females. Oikos, v.94, p.182-190, 2001. 
MAGURRAN, A.E. Ecological diversity and its measurement. Princeton University Press. Princeton, New Jersey, 179pp., 1988.

MINEIRO, J.L.C.; SATO, M.E. Brevipalpus papayensis Baker e Brevipalpus yothersi Baker (Acari: Tenuipalpidae) no Brasil: identificação e distribuição geográfica. O Biológico, v.79, p.88, 2017.

MINEIRO, J.L.C.; SATO, M.E.; RAGA, A.; ARTHUR, V.; MORAES, G.J. DE; SARRETA, F.O.; CARRIJO, A. Diversidade de ácaros (Arachnida: Acari) em Coffea arabica L. cv. Mundo Novo, nos municípios de Jeriquara e Garça, Estado de São Paulo. Biota Neotropica, v.6, p.115, 2006a.

MINEIRO, J.L.C.; SATO, M.E.; RAGA, A.; ARTHUR, V.; CANGANI, K.G.; BARBOSA F.V. Diversidade de ácaros (Arachnida: Acari) em cinco cultivares de duas espécies de cafeeiros (Coffea spp.) em Garça, estado de São Paulo. Arquivos do Instituto Biológico, v.73, p.333-341, 2006b.

MINEIRO, J.L.C.; SATO, M.E.; RAGA, A.; SOUZA FILHO, M.F.; SPONGOSKI, S. Incidência de ácaros em cafeeiro cv. Catuaí Amarelo. Bragantia, v.67, p.197-201, 2008a.

MINEIRO, J.L.C.; SATO, M.E.; RAGA, A.; ARTHUR, V. Population dynamics of phytophagous and predaceous mites on coffee in Brazil, with emphasis on Brevipalpus phoenicis (Acari: Tenuipalpidae). Experimental and Applied Acarology, v.44, p.277-291, 2008b.

MINEIRO, J.L.C.; RAGA, A.; SATO, M.E.; LOFEGO, A.C. Mites associated with coffee plants (Coffea spp.) in the State of São Paulo, Brazil. Part I. Mesostigmata. Biota Neotropica, v.9, p.37-46, 2009.

OCHOA, R.; AGUILAR, H.; VARGAS, C. Acaros fitofagos de América Central: Guía ilustrada. Turrialba, Costa Rica. CATIE, 251p., 1991.

PALLINI FILHO, A.; MORAES, G.J. DE; BUENO, V.H.P. Ácaros associados ao cafeeiro (Coffea arabica L.) no Sul de Minas Gerais. Ciência e Prática, v.16, p.303-307, 1992.

PEDRO NETO, M.; REIS, P.R.; ZACARIAS, M.S.; SILVA, R.A. Influence of rainfall on mite distribution in organic and conventional coffee systems. Coffee Science, v.5, p.67-74, 2010.

REIS, P.R.; TEODORO, A.V.; PEDRO NETO, M.; SILVA, E.A. Life history of Amblyseius herbicolus (Chant) (Acari: Phytoseiidae) on coffee plants. Neotropical Entomology, v.36, p.282-287, 2007.

REIS, P.R.; ZACARIAS, M.S. Ácaros em cafeeiro. Belo Horizonte: EPAMIG. 2007. 76p. (EPAMIG. Boletim Técnico, 81).

SILVA, E.A.; REIS, P.R.; ZACARIAS, M.S. Fitoseídeos (Acari: Phytoseiidae) associados a cafezais e fragmentos florestais vizinhos. Ciência e Agrotecnologia, v.34, p.1146-1153, 2010.

SILVA, M.Z. DA; SATO, M.E.; OLIVEIRA, C.A.L. DE; NICASTRO, R.L. Interspecific interactions involving Neoseiulus californicus (Acari: Phytoseiidae) and Agistemus brasiliensis 
(Acari: Stigmaeidae) as predators of Brevipalpus phoenicis (Acari: Tenuipalpidae). Experimental and Applied Acarology, v.65, p.319-329, 2015.

SPONGOSKI, S.; REIS, P.R.; ZACARIAS, M.S. Acarofauna da cafeicultura de cerrado em Patrocínio, Minas Gerais. Ciência e Agrotecnologia, v.29, p.9-17, 2005.

TEODORO, A.V.; KLEIN, A.M.; TSCHARNTKE, T. Temporally mediated responses of the diversity of coffee mites to agroforestry management. Journal of Applied Entomology, v.133, p.659-665, 2009.

TIXIER, M.S.; KREITER, S.; AUGER P. Colonization of vineyards by phytoseiid mites: their dispersal patterns in the plot and their fate. Experimental and Applied Acarology, v.24, p.191211, 2000.

WHITTAKER, R.H. Dominance and diversity in land plant communities. Science, v.147, p.250260, 1965.

Recebido em: 15/08/2018

Aprovado em: 12/01/2019 
Table 1. Mites on coffee plants in forest fragment and conventional coffee plantation: orders, families and species, and total of specimens. Monte Alegre do Sul, State of São Paulo, from October 2007 to October 2008.

\section{Acari}

forest fragment

coffee plantation

Ixodida

5

\section{Mesostigmata}

\section{Ascidae}

Asca sp.

2

Lasioseius sp.

1

Incertae Sedis

Africoseius sp.

1

Phytoseiidae

Amblyseius herbicolus

93

7

Euseius alatus

8

Euseius citrifolius 1

Iphiseiodes matatlanticae

119

1

Iphiseiodes zuluagai

2

Typhlodromus transvaalensis

2

\section{Prostigmata}

\section{Cunaxidae}

Armascirus sp.

2

\section{Erythraeoidea}

3

\section{Eupalopsellidae}

Exothorhis sp.

1

\section{lolinidae}

Homeopronematus sp.

1

Parapronematus sp.

1

\section{Stigmaeidae}

Agistemus brasiliensis

Agistemus sp.

1

Zetzellia sp.

Tarsonemidae

Fungitarsonemus sp.

1

48

Tenuipalpidae

Brevipalpus sp.

Tetranychidae

Eutetranychus sp. 
Oligonychus yothersi

Tydeidae

Brachytydeus formosa

Brachytydeus sp.

9

Pretydeus sp.

2

\section{Sarcoptiformes}

Oribatida

\section{Oripodidae}

Oripoda sp.

\section{Cohort Astigmatina}

\section{Acaridae}

Tyrophagus sp.

29

\section{Winterschmidtiidae}

Czenspinskia sp.

\begin{tabular}{lcc}
\hline species richness & 17 & 15 \\
\hline number of specimens & 284 & 265 \\
\hline diversity index $\left(\mathbf{H}^{\prime}\right)$ & 1.6 & 1.5 \\
\hline
\end{tabular}

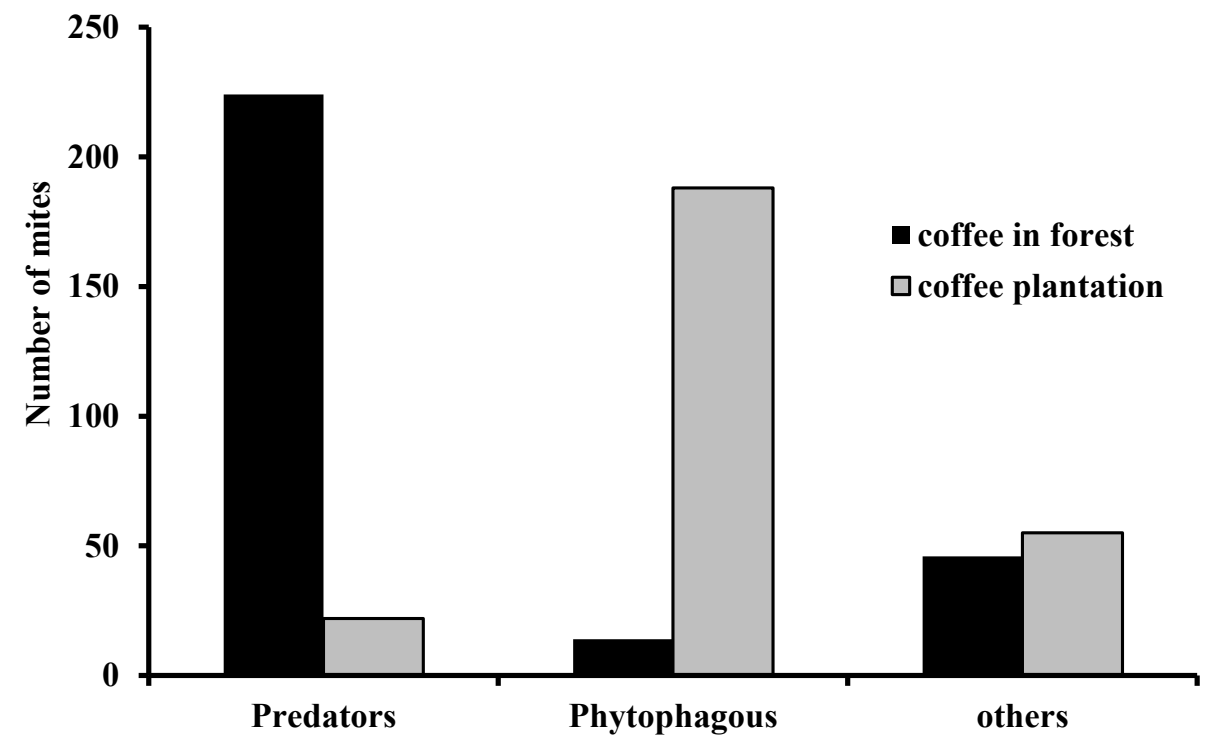

Figure 1. Abundance of phytophagous, predatory and others mites on coffee plants within forest fragment and conventional coffee plantation in Monte Alegre do Sul, State of São Paulo, Brazil. 

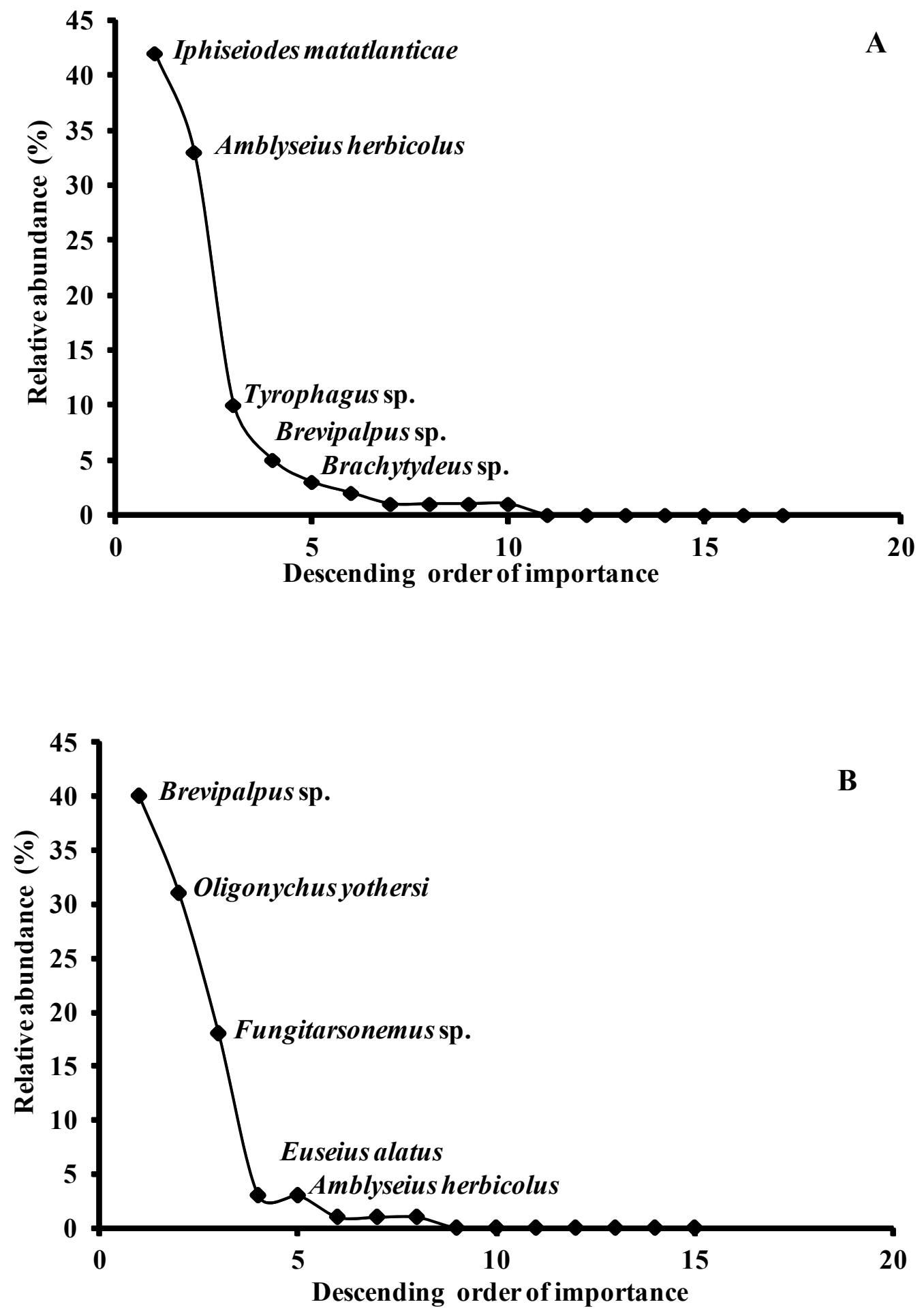

Figure 2. Relative abundance of mites collected from coffee plants within forest fragment (A) and conventional coffee plantation (B) in Monte Alegre do Sul, State of São Paulo. 